\title{
An Explaining of the Components of Occidentosis: A Plague by the West and Returning to Self-identity in Jalal Al-e-Ahmad's Thoughts
}

\author{
Jalal Nezafat \\ Department of Political science, Science and Research Branch, Islamic Azad university, Tehran, Iran \\ zghaeigy@gmail.com
}

\begin{abstract}
After World War II, new branches were added to sciences, especially the humanities. Due to the extensive interaction between the East and the West, the translation and summarization of the Western written works and the return of graduates to the country from abroad created a dramatic development in all affairs of the Eastern countries. One of the most important changes that took place was modernization, which swept across the various political, social, and personal domains of most Western societies and affected many people in these societies. The clash between tradition and modernity led to the overshadowing of traditional beliefs and the personal and national identities of Eastern societies in interaction with the West; thus, it made some Eastern intellectuals, writers, and thinkers oppose the teachings of modernism so that they strongly emphasized the necessity of returning to self-identity and native traditions. Based on the above approach, the present article seeks to answer what Westernization and return to self-identify in the thoughts of Jalal Al-e-Ahmad mean. It can be said that by turning to fiction, essay writing, travelogue writing and bringing up diverse social themes in different forms, Sayyid Jalal Al-e-Ahmad brought up the concern for returning to self-identity and Westernization, and in his book, "Occidentosis: A Plague by the West", he criticized modernity. Then, he emphasized identity and historical traditions that are discussed in detail in this study. In addition, in this research, while analyzing the political life of Jalal Al-e-Ahmad through descriptiveanalytic method, his thoughts and views on Westernization are analyzed and elaborated on with an emphasis on a postcolonial theory by relying on library resources.
\end{abstract}

Keyword: Westernization; Jalal Al-E-Ahmad; Post-Colonialism; Colonialism, Identity

\section{Introduction}

One of the most effective tools to transfer human thoughts and events is through their registration and writing. Occasionally, skilled writers rise in the history of each country that write their own ideas in the most beautiful way and have a profound influence on the society of their time. Undoubtedly, Sayyid Jalal Al-e-Ahmad was one of the prominent Iranian writers who began his writing career from around the age of sixteen or seventeen and published his first work at the age of twenty. The result of his thirty years of writing is about forty-five stories, articles, travelogues, and translations, some of which were unique in their time. 
Jalal Al-e-Ahmad mobilized his society in the fight against all the manifestations of injustice and oppression through his long and short stories, with a profound national and religious commitment and through writing social critical articles. Al-e-Ahmad's purpose was not merely writing; rather, for him, the writing was an instrument for the promotion of the human community in general and Iranian society's achievement of freedom, justice and the elimination of existing class discriminations. Al-e-Ahmad is one of the writers who paid attention to all aspects of his society, elaborated on the problems of the society with his eloquent style of writing and proposed solutions for them. In this regard, one can refer to the book "Occidentosis: A Plague by the West" which shows that he has a school of thought in the field of social affairs (sociology), although he himself has never made such a claim. He has correctly identified the various situations and systems in society and has sought to inform the society. In other words, Jalal Al-e-Ahmad has called Westernization a social disease and has identified its treatment and it is nothing but the liberation of Third World nations from the colonial yoke and Western exploitation. He defines an international political economy, on one side of which there is the machine-building and technology-building "West" with features such as high welfare, lower rates of mortality, efficient social systems, high per capita income, and widespread social justice. On the other hand, there is Third World, which is the consumer of the "West's" industries; a West, who is the plunderer of raw materials and their resources. The result of such a situation is the creation of a wide chasm between the two poles mentioned. Paying attention to the West, as a leading colonialist, is concerned about colonial greed that has created unrest over the past three hundred years and has endangered national and indigenous colonized cultures. He regards this as moving from the static pole to the "dynamic" pole, and expressing concern about it, he introduces the return to self-identity and paying attention to the indigenous material and immaterial resources of the colonies as the only way to escape from Westernization. Thus, the present article seeks to find an appropriate answer to the question that what the position of Westernization and the returning to self-identity is in the thoughts of Jalal Al-e-Ahmad. It can be briefly said that Sayyid Jalal Al-e-Ahmad expressed the concern for returning to self-identity and Westernization; and in his book, "Occidentosis: A Plague by the West", he criticized modernity; then, emphasized identity and historical traditions, which are dealt with in detail in this study from the point of view of the postcolonial theory.

\section{Postcolonial Theoretical Foundations}

Prior to addressing the theoretical foundations of post-colonialism, it would be worthwhile to mention the mainstream and influential trends on the formation of post-colonialist theoretical foundations. In this section, these trends are first evaluated based on the development of postcolonial theory in the geographic dimension and its developmental waves from a theoretical perspective. Accordingly, approaches that overshadowed the theory in the geographic dimension are:

1. Subordinate Study Approach: This approach has continued to work in the Indian subcontinent, then in the Latin American region. The main goals of this approach are to examine the role of colonialism and nationalism in India's political history. In this regard, followers of the subordinate study approach consider liberal, Marxist, and nationalist analyzes of colonial history in India insecure and unreliable.

2. African Approach: A branch of this approach is also found in the United States and Canada. However, it should be noted that, on the one hand, cultural and geographical differences and, on the other hand, the distinctive features and traditions of the aforementioned regions, in turn, have led to independent growth and development. This applies both to the African approach and to the Indian subcontinent approach. In the sense that the region of Africa and the Indian subcontinent region are both considered to be Third World, and its intellectuals and philosophers have achieved a theoretical response to Western culture and philosophies by a profound understanding of their contemporary philosophies and thoughts, such as Edward Saeed's Orientalism and Jalal Al-e-Ahmad's Westernization. 


\subsection{Distinctive Theoreticians of the Westernization Discourse}

Here, it is necessary to explain the idea of Westernization and its relationship with the postcolonialist theory briefly. The thought of Westernization, including rational discourse and ideas, dominate Third World countries, hence, Iran before and after the Islamic Revolution. Among the key figures of this discourse are Sayyid Ahmad Fardid, Sayyid Jalal Al-e-Ahmad, Dariush Shayegan, and Reza Davari Ardakani. In this regard, in the following table, the thoughts of the three thinkers on Westernization discourse are briefly analyzed and explained.

\section{Table 1: Distinctive Theoreticians of the Westernization Discourse}

Thinkers

Ahmad Farid
Fardid put forward the term "Westernization" for the first time. Prior to his trip to Europe, he criticized many Western philosophers such as Descartes, Kant, Fichte, Schelling, Hegel, Schopenhauer, Bergson, as leaders of Western civilization and meanwhile, wrote articles in the journals of that time. However, after leaving for the West, he realized the truth and nature of the culture and civilization of the West and considering the nomenclature, he coined the term "Westernization". From his vantage point, Westernization comes in varieties and it can be analyzed from various points of views that will be dealt with in the third chapter. Thus, according to Fardid, "From the time of Greece to the present day, Westernization is the same as tyranny," because, according to Fardid, tyranny is the same as Zeus and the Greek Neows, which have common roots with Deus in Latin, Div in Persian and Do in Sanskrit (Hikmat, 1395). On this basis, Fardid considers the idea of Westernization associated with many concepts such as nihilism, Greekism, historical periods, and trickery of night and day (Fardid, 2016: 21). He also considers "the geographical and geopolitical East and West" the cause of Westernization (Dibaj, 2005: 274).

At the beginning of the book Occidentosis: A Plague by the West, Jalal Al-e-Ahmad considers himself beholden to Ahmadi Fardid for using the term Westernization and honestly points out that his understanding is different from Ahmad Fardid's understanding. Al-e-Ahmad saw Westernization as a fascination and blind emulation of the facade of Western capitalist culture namely Europe and America. However, not only did he not consider the socialist facade of Western culture a danger, rather he considered it necessary and an elixir for the morbid East provided that it does not conflict with the legacy of Eastern culture, especially Islamic culture. He also proposed themes such as "Westernization", "Betrayal of Intellectuals", "Asia against the West", "what it had itself", "Western loneliness", colonization, imperialism, "mechanism", "Freemasonry" and themes like that, he sought to solve the social crises of his time. Considering that in the next section, the concept of Westernization in the thought of Jalal Al-e-Ahmad is analyzed analytically, in this section, the most important intellectual categories of his thoughts are briefly discussed in this section.

Defending the Eastern identity, Dariush Shayegan, criticized the West and European modernity fundamentally in the 40 s and 50s. Shaygan discussed his ideas by bringing up issues such as "society values", "intellectualism and the absence of religious intellectualism", "the dialogue between cultures", "Westernization", "the relation between "religion and revolution" and the creation of concepts such as "cultural mutation", "double illusion", " The Ideology of the Sunnah", "fragmentary identity and ambulatory thinking". According to Shayegan, Westernization transforms the foundation of Asian civilizations 
Reza Davari Ardakani

and destroys the ethnic memory. He uses the notion of double illusion to analyze this. From his point of view, "the double illusion manifests itself in two negative aspects of Westernization and alienation and generates a period of decline. The period of decline is the period of alienation. The reason it is alienation is that our fascination with the West and our mental paralysis against its stunning products destroy the reminder that is necessary for our traditional thinking. The reminder that used to lead us to the light of the Prophet Muhammad; therefore, it hurdles our way towards the center of Western thinking and also to the center of manifestations of ethnic memories (Shayegan, 2009: 87). In the book Asia Against the West, Shayegan seeks to seriously address the philosophical and cultural challenge facing the West. In this work, he expanded the Jalal Al-e-Ahmad's concept of Westernization and provided a deep insight into the issues that included the encounters of the Third World's people with the hegemony of Western culture (Shayegan, 1993: 189).

The concept of Westernization is one of the most important categories of his thought, which, for the sake of discussion, is borrowed from Ahmad Fardid. He knows the West and the East as a world. He does not regard the world as a set of things or good and bad things, but a condition and possibility for the creation of forms of tradition and relationships. Of course, his point of view on West is ambiguous. He writes somewhere that "The West and the East are each a world, and the world is neither a set of objects nor something like Durkheim's collective soul. The bright world is when it gives the objects a possibility for existence, revelation, proximity, dimension, precedence and antecedence, importance and unimportance, largeness and smallness. The East and the West create the possibility of the emergence and realization of forms of traditions, relationships, customs, and rules, not sets of things" (Davari, 2004: 145-146). In his view, the West is an incident and, at the same time, a history. The beginning of the West happened in Greece, which was also the beginning of philosophy. He generally views the West and the East as being of a nature (Davari, 2004: 146).

\section{Source: The author}

According to the discussions above, it should be noted that the formation of post-colonial discourse in opposition to the foundation of Western thought is one of the examples of the presence of native trends in the Eastern or Third World countries. In fact, colonial anti-colonialist discourse is an attempt to decompose the "self /the other" opposition of the Western attitude; that is removing the attitude of considering Eastern societies as "the other" and the supremacy of "Western self". Jalal Al-e-Ahmad should be considered as one of the pioneering (avant-garde) representatives of the post-colonialist discourse in Iran; since his approach to post-colonial writing reaches its peak in his non-fiction works, "At the Service of the Intellectuals", "Occidentosis: A Plague by the West" (Qasemzade, 2013: 45). On the other hand, it must be stated that the story "The Tale of Beehives" has had an even more significant influence on the formation of the Al-e-Ahmad's anti-Western discourse of Al-e-Ahmad, and was written using a post-colonialist approach. In the story "The Tale of Beehives", which was written after he left the Tudeh Party, Al-eAhmad's earlier critique of the capitalist system is not so pure and native due to his propensities toward the party, especially his Marxist tendencies (Qasemzadeh, 2013: 58). In fact, the theme of the book is about the events that followed the coup d'état of August 19, 1953, in which British colonization was substituted by American colonization. He paid special attention to this event and portrayed it through the story of The Tale of Beehives. Therefore, from the point of view of post-colonial writing, the writing of the story The Tale of Beehives is a cultural response to Westernization and Iranian consumerism against the West (Al-e-Ahmad, 2001: 101). In fact, Al-e-Ahmad portrays his interpretations and views based on two levels of colonialist thinking, namely political and economic exploitation and cultural exploitation, and presents ways to emancipate from colonization by returning to self and reviving the national and indigenous identity of Iran. Thus, like other post-colonial writings, it captures "the tendency towards the cultural and political 
independence of nations" and "resistance against colonialism". Thus, at a glance, we can state the foundations of postcolonial theory as follows:

1. Post-colonial rulers (the West) seek comprehensive measures to dominate and control subordinate populations (non-Western).

2. Post-colonialism seeks to address cultural structures and influencing them.

3. Post-colonialism seeks to promote Europeanism and concepts such as freedom, equality, and justice.

4. Post-colonialism is constantly critical of Third World and it seeks to create a discourse on the superiority of the West (itself) and the backwardness of the East (the other) (Taebi and Heydari, 2015: 57).

\subsection{Post-colonialism and Jalal Al-e-Ahmad}

The frustration of political activities and familiarity with the critique of Western intellectuals on modernity and the West led Al-e-Ahmad to study the indigenous and traditional life of the Iranian people and led to the writing of "Corazon" and "Tat people of Block-e Zahra", as well as the "The Tale of Beehives" and then "Occidentosis: A Plague by the West", "At the Service and Betrayal of the intellectuals". In the last two works, he considers Westernization and Westernized intellectuals as an economic and cultural unit that has collapsed against the invasion of machine and modernity. Of course, he considers development inevitable at this time (contrary to The Tale of Beehives), but he did not believe that "personality, the existence and the culture of the place and surrender to what mechanism desires and to experts that are unfamiliar with us, our ways and our life" (Al-e-Ahmad, 1974: 13). As a result, he tries to pay attention to the history of this region and the customs of its indigenous people in the face of this flood of Westernization, so that "in the midst of this shortage we have, the only preference of those from Khark, which is being from Khark, is not wasted (Al-e-Ahmad, 1974: 79). In addition, at least, a legacy remains from indigenous people for the future Iranians (Shahshahani, 1992: 86), which is a reference for the Iranian identity in contrast to the identity of other nations. In fact, this is a different understanding of the West, which appears most in criticizing the Westernized governments that, in Al-e-Ahmad's assumption, are appointed by the West. Ale-Ahmad gradually approached the concept of Westernization and cultural colonialism of the West to eliminate the culture and customs of the nations of the Third World in order to exploit as much as possible. Paying attention to Westernization also turns him towards religion as the main element of Iranian identity and native culture, and proposes the idea of Islamic alliance here. However, his nativism, which took place with a modern look at the Iranian-Islamic tradition, was adjusted gradually and with attention to Islamic tradition and ultimately led to an emphasis on self-criteria in cultural and social assessments and even humanities. However, he emphasizes the Islamic tradition, as a rebirth away from Westernization, but not traditionalism. In other words, Westernization and Western cultural colonialism show that particularly postcolonialist discourse is heavily influenced by components based on nativism and returning to self-identify with a political and cultural function.

In other words, "Occidentosis: A Plague by the West" and "At the Service and Betrayal of Intellectuals" are post-colonial texts that illustrate the implications of the colonial presence as well as the Westernization of the society and elaborate on the role and position of intellectuals in this process. Accordingly, it should be stated that the basis of Al-e-Ahmad's thinking in his works is, in fact, finding the contradictory layers and contradictions arising from the confrontation of two conflicting cultures as a result of Western cultural colonialism, and the two abovementioned works are no exception to this rule. Forms of his thoughts in the works are somehow a contrast of the formation of the arrogant West and the subordinate East (in a sense, the colonial /colonized relation). In this unequal image, Iran, in particular, becomes a symbol of a colonized society that unconsciously and in vain exchanges its national capital in exchange for industrial goods and mechanism after the coup d'état of August 19, 1953. Therefore, Al-e-Ahmad considers cultural exploitation to be the prelude to economic and political exploitation. He considers returning to self- 
identity and nativism the only way toward national consciousness. From his point of view, removing ideology and Europe-centeredness (Westernization) are factors justifying the presence of foreigners and imitating the West, and this, in turn, is the most important factor of colonialism and Westernization. Therefore, it has to be treated with nativism and identity retrieval. Accordingly, some of the components of the post-colonialism theory, including the conflict between the East and the West, colonialism, identity, and Europe-centeredness (Westernization), and the role of intellectuals in this regard can be studied in Jalal Ale-Ahmad's views and ideas. The discussions above will be further analyzed and elaborated in the following sections. It should also be stated that according to the studies on his works, Al-e-Ahmad's views on these components were taken with a political-cultural approach and he analyzed the issues from within the society of his age.

\section{Sayyid Jalal Al-e-Ahmad's Political and Social life}

Jalal Al-e-Ahmad mobilized his society in the fight against all the manifestations of injustice and oppression through his long and short stories, with a profound national and religious commitment and through writing social critical articles. Al-e-Ahmad's purpose was not merely writing; rather, for him, the writing was an instrument for the promotion of the human community in general and Iranian society's achievement of freedom, justice and the elimination of existing class discriminations. From when he was young until the end of his short life, Al-e-Ahmad always moved in a gradual intellectual evolution and was transforming like a flowing river. He was a committed intellectual, an informed writer and a brave fighter in a society suffering from tyranny in the silent days among unaware people. He used an eloquent and impressive writing, a bright and decisive intellect, a familiar culture, an extraordinary honesty, a popular approach and relied on the cultural richness of the East and familiarity with Western culture, clearly depicted the conflicts between the Western culture and the society colonized. No significant issue can be considered that has been addressed in this society and at his time that Al-e-Ahmad has not made passionate, courageous, and humane judgments about (Jahani, 1983: 67).

In fact, the political events of the 1940s until 1960s led to the arrival of Jalal to the political arena; he experienced the Tudeh Party, the Third Force, and National fronts and social struggles; but that was not enough for him. He wanted to understand the depths of the community and know where the unresolvable problem lies. He saw the problem in the imitating the West and living a Western material and cultural life. Hence, he was more concerned about cultural cessation and believed that the society should rely on its own traditions and it should be aware of the Iranian-Islamic heritage and its significance (Dastgheib, 1997: 112125). Accordingly, in order to examine Jalal Al-e-Ahmad's life, it can be classified according to the decades of his life as follows:

\section{Phases Explaining}

Phase 1 The social conditions existing at this time did affect Jalal's intellect. In the confrontation between the clergy and the intellectuals that had emerged at the time of the Constitutional Revolution and had ended with the relative overwhelming of the intellectuals and the isolation of the clergy, Jalal's father, who was considered a well-known and trusted clergyman, suffered losses. Consequently, the conditions made his father a frustrated, angry, secluded, angry, and harsh man. The harsh strictness and dictatorial behaviors of Jalal's father made life hard for Jalal and his family, ultimately leading to Jalal's frustration from home and his outburst against his father. (Al-e-Ahmad, 1990: 177). During these years, Jalal stood against his father's will, which was the tendency towards traditional religion and maintaining faith to religious principles, and moved to the forefront of political and party movements (Al-e-Ahmad, 1997: 67). 
Phase 2 In 1953, Al-e-Ahmad put religion aside and joined the Marxist Toudeh Party. After a short while, he achieved great positions in the party, especially in the publication department. During this period, he had practically distanced himself from religious thoughts. He got familiar with Ahmad Kasravi's works in his junior and senior years of high school. The conflicts of World War II are factors deemed effective in changing Al-e-Ahmad's thinking. He left the Toudeh Party following widespread dissension between Khalil Maleki and party leaders; however, he showed that he was not a mere follower and he specified his conditions when leaving the party (Shafiei Ghahfarkhi, 2009: 73-74). Indeed, the reason for his separation from the Tudeh party was that observing the party's intrinsic contradictions, Al-e-Ahmad and his associates criticized the leadership and general orientation of the party and according to their confessions, they could not accept that an Iranian party was a tool in the hands of a foreign country. In the same year, he published the book "The Tudeh Party at Crossroads of Doubt" about controlling the external factors on the performance of party leaders (Al-e-Ahmad, 1997: 344). After Jalal left the Tudeh party, he suffered from a serious intellectual vacuity, but began to return to his own identity with regard to his origin of thoughts and religious attachments.

Phase 3 After the coup of August 19, 1953, he completely abandoned politics and focused on cultural and intellectual activities. During his intellectual activities in this period and due to the adverse consequences of interacting with the West, Al-e-Ahmad introduced the theory of Returning to selfidentity and confronting the effects of Western culture and civilization. Writing books such as "Occidentosis: A Plague by the West", "At the Service and Betrayal of Intellectuals" and "The Curse of the Earth" are the fruits of his social and political ideas in this period. Jalal Al-e-Ahmad's considers his book "Occidentosis: A Plague by the West" a turning point in his career as a writer and thinker.

In this period, his ideas took distance from the existentialist approach, it made use of the forefront of Westernization, returning to self-identity, and nativism to defend religion and tradition, and in a sense, the fourth period of his life began with the approach of returning to self-identity and religion.

Phase 4 The incident of June 5, 1963, had a profound effect on him and led him to find out the importance of the role of religion and the clergy, and he took a special interest in Imam Khomeini. In this regard, in the book "At the Service and Betrayal of Intellectuals", he wrote, "The first plan of this book was made on June 5, 1963; its motivation was to respect the bloodshed of people from Tehran on June 5, 1963, that the intellectuals ignored it entirely (Al-e-Ahmad, 1969: 15). Thus, it became clear to Al-e-Ahmad every day that it is possible to preserve the native customs and traditions by turning to the Shia religion (Boroujerdi, 2003: 117). Indeed, the final years of his life are the return to self and religion. Thus, in these years, Jalal Al-e-Ahmad's ideological turnaround toward a philosophical self and the search for ethnic-national identity is observed.

\section{Source: The author}

According to the discussions above, his political and social life can be divided into four main phases: the first period, life with the teachings of a traditional, religious patriarchal and clergy family, the second period, the frustration from religion and tradition, and joining The Tudeh Party, which was in opposition to tradition and religion. The third period was his separation from the Tudeh party due to the internal contradictions in the party. In other words, he began to have existentialist attitudes. In this period, Jalal was initially focused on political activity, but in the middle of this period he set aside political activities, he became suspicious about the Tudeh Party. He engaged in cultural activities and got familiar with Albert Camus and Dostoevsky's works. In the end, once again, approaching religion and tradition, he uses religious and traditional components as a defense against Westernization; thus, the fourth period of his life begins with the writing of the book "Occidentosis: A Plague by the West" and the social changes of the year 1963. In addition to proposing theoretical discussions on Westernization and intellectuality (discussed in the next section in detail), he used a different approach in his political activities. Thus, the fourth period of his political life is of great significance with regard to the writing of his most important works, in particular, the writing of the book "Occidentosis: A Plague by the West". 


\section{Elaborating on the ideas of Sayyid Jalal Al-e-Ahmad}

In general, Jalal Al-e-Ahmad embarked on literary, cultural, social, and political activities when Iran faced fast internal and international changes and challenges. For example, in the 1940s, during Reza Shah's fall, the intellectual environment of Iran was largely in the hands of the political left wing movement, where the role of the Tudeh party was very prominent. In addition, the defeat of the Iranian national movement led by Mohammad Mossadegh, which resulted in the coup of August 19, 1953, created a kind of frustration among Iranian intellectuals. After the coup, the scope of social and political freedom was gradually limited, and intelligence and security surveillance were applied to the areas of thought, speech, and writing. According to previous discussions, Jalal's intellectual approach can also be outlined in four sections:

- The period of adherence to religion

- The period of a tendency to Marxism (membership in the Tudeh Party)

- The period of a tendency to existentialism

- The period of returning to self and practicing religion

In fact, Al-e-Ahmad, like other intellectuals of his age, was influenced by the current political left wing. He did not enjoy much theoretical and philosophical knowledge and support and was living a politically demotivated environment that was accompanied by semi party and group clashes. In other words, Iran's intellectual discourse continued to develop toward leftwing politics and political demotivation. Meanwhile, our intellectuals suffered from poor resources and lack of methods tailored to the fields of study and research. Due to the dominance of the left wing, the intellectuals of this period of Iran's history had a tendency toward the socialist literature, which originated from the Soviet Union and then France and in some cases, some Eastern European countries. These intellectuals often lacked the necessary theoretical and philosophical support, and their studies were more focused on the social and economic ideas of the school of Marxism. The awareness of these intellectuals of the social and political issues of Iran, Third World, and the West was limited to a few works, among which one can refer to the writings of Tibor Mende, Jose Du Castro, Frantz Fanon, and Aimé Césaire (Al-e-Ahmad, 1978: 117). In this regard, it seems that some of the intellectual components of the philosophy of existentialism are obviously observed in what Jalal Al-eAhmad mentions in the context. Thus, it must be stated that one of the aspects and approaches that Al-eAhmad has been influenced by is the existentialist philosophy. The principles of this philosophy are the human freedom from determination, his responsibility, his ability to shape his own nature and destiny, and the sense of duty towards others.

After Al-e-Ahmad returns from Hajj journey in 1964, a kind of realistic return to pure Islam became also evident in his thoughts. It looks as if Jalal somehow turns to a true religion devoid of prejudice and superstition. He believes that "Today, religious truths are left under the veil of vanity. Since the dense clouds of fanaticism and prejudice now overshadow the true religion, save the luminous gem from underneath all the prejudice and reach the core by breaking the shells; whether a man wants or not, he is godly and seeking God is inherent in his nature and is inherently fixed" (Al-e-Ahmad, 2000). Therefore, Jalal entrusts the clergy and intellectuals with the task of clarifying the religion, because this can create a very clear and progressive system in society. Finally, it should be stated that the fields and intellectual approaches that influenced the formation and expansion of Jalal Al-e-Ahmad's thoughts were Islamic religious thoughts, Kasravi's thoughts, Marxist (Leninist, critical) ideas, existentialist views (Camus, Sartre), nihilism ideas (Kafka, Sadegh Hedayat), third force theory (influenced by Khalil Maleki's thoughts), and affiliation school (with emphasis on the role of external factors in the non-development of Third World countries). With this introduction, Jalal Al-e-Ahmad's thoughts can be examined and analyzed in three political, social, and cultural sections. 


\section{Thought}

Political

Social

Cultural
Table (3): Al-e-Ahmad's political, social, and cultural Thoughts

\section{Explanation}

Jalal Al-e-Ahmad can be considered as an influential thinker of the 1960s and 1970s. In fact, his critique of intellectuals and intellectual movements after the Constitutional Revolution caused a break between contemporary culture and the culture of Western modernity. This was more than any other factor due to the publication of two political and social books, "Occidentosis: A Plague by the West" and "At the Service and Betrayal of Intellectuals". By publishing these two books and trying to provide solutions to organize the political and social turmoil of his time, he was introduced as a political thinker. Accordingly, if we define political thought as opinions on the organization of political aspect of human life, then the Jalal Al-e-Ahmad's political ideas in the 1960s can be called "returning to self" (Manouchehri and Abbasi, 2010: 301).

According to Al-e-Ahmad's statement that "Our time is a time of escalation of the social conflict" (Al-e-Ahmad, 1962: 189); he sought to portray while finding the causes of social injustice at his time. According to Al-e-Ahmad, the source of many social and even cultural depravations and injustices in Iran is the abandonment of traditional heritage (originality of self and indigenous identity) and surrender to the West (the other) and its extreme imitation, along with the lack of proper knowledge of the roots of the progress of the West. Therefore, he primarily focused on the critique of modernism and the West.

Jalal Al-e-Ahmad noted, "If we can think of a role for our culture, only the prominent personalities can eventually lead this country in this social turmoil caused by the crisis of Westernization. The purpose of our culture should not be and cannot be to reconcile and harmonize people so that everybody withstands and overcome all existing situations. Particularly for us, who are in this period of transformation and crisis and in a kind of social purgatory, only by the help of self-sacrificing people, and principles, that call these people maladjusted, stubborn and unbalanced in the commonplace of their psychology, can we endure the burden of all this transformation and organize this social turmoil" (Al-e-Ahmad, 1963: 187-188).

Source: The author

\section{Jalal Al-e-Ahmad and Westernization}

Jalal Al-e-Ahmad has various interpretations of the West; for example, he likens Westminster to old age, like when the crop ages, it empties from within and only a shell remains outside. Westernization, according to Al-e-Ahmad, means that a nation is left out of culture, principles, faith, religion, and ideology, and only an appearance of a nation remains; but this nation lacks content, security, and reliance.

In his opinion, Westernization means an illness, a bilateral transaction, but in favor of one side and to the detriment of the other. That is, a system of lords and peasants, in which the West and their countries always dominate the weak and growing countries to extract life out of them; Westernization is a modern way of colonization and exploitation. Westernization means the complications of a particular economic (inevitably political) relationship between two nations, whose relationship is not a transaction or convention, but something like the relationship between the master and the servant, what you call "neo-colonialism" (Forsati Jouybari and Rahimi Doon, 2012: 20).

The most famous work of Al-e-Ahmad, which is a kind of manifesto, is "Occidentosis: A Plague by the West". Reza Barahani writes about the significance of this book: "Al-e-Ahmad's Occidentosis: A Plague by the West is the first Eastern treatise that clarifies the situation of East against the colonial West, and is probably the first Iranian treatise that has a social value on a global level" (Mirsepasi, 2006: 176). In 
fact, the works of Jalal Al-e-Ahmad, especially Occidentosis: A Plague by the West and at the Service and Betrayal of Intellectuals, which includes his social and analytical articles, have been written in response to the social crisis of his time. In Occidentosis: A Plague by the West, Al-e-Ahmad, in his opinion, seeks to find the causes of the most important problem of the Iranian society, which has caused its corruption and decay and describe it like this, "Westernization is like being struck by the plague. Or heatstroke or frostbite, if you may. At least it is something like becoming of age. Have you seen how it rots the wheat? From within. The healthy shell remains, but it is only a shell. Anyway, we are talking about a disease. A complication attacks from outside and grows in an environment ready for illness (Al-e-Ahmad, 1373:21). In this context, he writes in a different section of the book on the outset of the study of social diseases of his era, "As we look at history, it appears that we have always been interested in the West, (even) we have mentioned the term west before foreigners call us the East (Al-e-Ahmad, 1995: 39).

Al-e-Ahmad continues to point out that in this era, we are looking at the West more than we consider the East, and the West here means the geographical West that includes the Mediterranean, Greece, Lydia and the Nile valley. When he wants to talk about the motives and causes of the East (Iranians) paying attention to the West, he goes beyond the geographical definition of the West and even considers the factors of paying attention to the West geographical. Jalal Al-e-Ahmad writes in this regard, "Perhaps our attention to the West was due to the fact that in this dry wide dessert, we had always waited for the Mediterranean clouds" (Al-e-Ahmad, 1995: 49). In other words, some considered adding the geographical concept to the definition of Westernization based on Al-e-Ahmad's need to broaden the concept of the West to achieve a certain kind of philosophy of history (Mesbahipour, 2003: 149).

However, Al-e-Ahmad describes the characteristics of the people who have been subjected to the West as follows, "A Westernized person has no personality; he lacks originality. He, his house, and his words do not show anything special, it is an amalgam of a solitary character, devoid of characteristics. Because he is not safe, he pretends; meanwhile, he is smooth-spoken and good-tempered. He does not trust his audience, and because suspicion dominates our times, he never pours his heart out. His only characteristic that may be conspicuous is the fear. If people devote their entire character to their specialty, here, a Westernized person has no personality, no specialty, only fear. The fear of tomorrow, the fear of dismissal, the fear of anonymity, and the fear of being discovered as empty, makes it heavier." (Al-e-Ahmad, 1963: 128). Accordingly, the phenomenon of Westernization appeared as the most important political-social notion Jalal proposed in the book "Occidentosis: A Plague by the West" and in criticizing the society and the government. Two meanings can be drawn from Jalal's notion of Westernization. The first implies the lack of a socio-cultural identity in Third World nations; on this basis, Westernization is "a set of complications that occur in the culture, the civilization, and the thinking of people at a point in the world. It lacks tradition as a reliance; it lacks continuity in history, it lacks transformative grading; it is merely a fruit of the machine (Fadaei Mehrabani and Moini; 2017: 713). The second conception of Westernization from Jalal's perspective was that "It is only by undermining the cultural religious context of the contemporary people that one can prepare the ground for the invasion of the West" (Al-e-Ahmad, 1970: 22). In this regard, in his exploration of the historical origins of Westernization, Al-e-Ahmad referred to the invasion of native northEastern nations as well as Alexander from the northWestern lands of the Iranian plateau, as well as the Muslim invasion of Iran from the deserts of the Southwest. He believes that the era of Alexander's invasion and the Greek rule over Iran is the first occurrence of pretending to be westernized among Iranians. Following this stance, Al-e-Ahmad calls the arrival of military advisers, businesspersons, pilgrims, and tourists in the Safavid period as another period of the advent of Westernization in Iran. Thus, in his view, the backwardness emerged as a result of Westernization, the ineffectiveness of the intellectuals, the passivity of the clergy, and the confrontation of the two aforementioned tends. The feeling of Iran's backwardness and progress in the West creates Westernization in Iran. Al-e-Ahmad describes several factors that cause the formation of Westernization in Iran: 
1. The historical inclination to the West

2. The inability and fear of making machines

3. Feeling humiliated and losing cultural identity

4. Imitating Western facade and neglecting the historical course of Western civilization

4. The clergy's retreat in front of the machine

5. Westernized intellectuals

6. Dependent governments (Al-e-Ahmad, 2002: 22).

In his book, Al-e-Ahmad enumerates a series of social and political issues as signs of Westernization. These include the destruction of villages, the influx of villagers into cities, the conflict between the city and the countryside, the inconsistency between cities and villages, the force to consume cars, unemployment of workers, disappearance of traditional industries and "artisanal" due to presence of the machine, the lack of social security, the contradiction between primitive, ancient and superstitious beliefs with the modern culture derived from the machine. Other factors include the belief in magic and prayer and Spell, liberating women (in a Western-style), that is simply allowing them to show themselves on the streets, the incompatibility of the educational and the economic system. Educating students without providing opportunities for their work, the contradiction between the state and the nation, the country's economic and military dependence on the West, avoidance of Persian language and the like are also signs of Westernization (Bashiri, 2012: 87). In the meantime, he emphasizes the role of machine or technology in expediting the process of Westernization. Furthermore, in the book Occidentosis: A Plague by the West, the concept of Westernization sometimes declines to acting like foreigners, dandyness, and sassiness; obvious symbols and signs of modern Westernization are mistaken with the phenomenon of Westernization, "We are like a nation alienated from our clothes, home, food, literature, and press, and most dangerously, we cultivate foreigners in our culture. (Al-e-Ahmad, 2002: 67).

Additionally, Al-e-Ahmad believes that Westernization happens in a country that is a consumer and importer of machines and has a consuming backward economy. Therefore, he believes that coping with the factors of backwardness and turning Iran into an advanced country would prevent the formation or expansion of Westernization. His proposals for removing backwardness in Iran include:

1. Planned settlement of nomadic tribes (Ashayer)

2. City planning

3. Pay attention to the needs of mechanized agriculture

4. Media independence

5. The independence of the country's leadership

6. Limiting the dominance of military forces on Iranian society

7. Implementing true democracy

8. Building and mastering machines

Thus, according to Al-e-Ahmad, in the last three centuries, the western world matured by the industrial revolution and "feudalism" gave way to urbanization. In the last three centuries, by the help of machinery, the West made vast achievements and required the turbulent market in the world, on the one hand, to obtain cheap raw materials, and on the other hand, to sell its products. In the same two or three 
centuries, we fell asleep behind our shields against the Ottomans, and the West not only tore the Ottoman empire and made a club out of its every bone for the rainy day of insurrection of the Iraqi, Egyptian, Syrian, and Lebanese people, but it came to us soon too. I regard this the cause of Westernization (Bashiri, 2012:49).

Furthermore, Jalal writes in the book Occidentosis: A Plague by the West, "In the Middle East, along with the dawn of the Renaissance in the West, investigation of medieval beliefs takes place and religious conflicts and wars enhance; we started exactly where the West finished. We stood where the West sat. When the West woke up at its industrial dawn, we went to sleep with the seven sleepers (p. 55).

In general, it should be acknowledged that, as we understand from Al-e-Ahmad's definition of Westernization, this phenomenon results from turning to Western culture and civilization, without having a base and support inside. In his view, Westernization is the abolition of traditions, opposing them, in order to implement the path of Westernization and mechanization; therefore, the first basis of rootlessness and alienation, or as he puts it, "Westernization" is the conflict between tradition and indigenous culture and the culture and manifestations of Western civilization. Jalal does not limit Westernization to contemporary Iranian history; in the book Occidentosis: A Plague by the West, he began the historical debate from the beginning of interest in Greece in the Parthian period and portrayed the history of the invasion of the West and the East, which led to their dominance over us. Finally, he also pays attention to the First and Second World Wars in this regard (Dastgheib, 1993: 15).

In addition, it is worth noting that the book Occidentosis: A Plague by the West was written in 1962 after Jalal's detachment from left trends and his return to religion; therefore, in this book, there are attacks on the world of "communism". (P. 25-26). However, one can also find signs in his previous works in a sporadic way; for example, Jalal's explanation of economic issues is similar to the explanation of left-wing groups, and he speaks using the language of "materialism", "We are not negating or rejecting the machine. Never! Machine's widespread use is determined by history (p. 27). "We are not developing nations, we are not the car makers, but in the face of economics and politics determination, and the confrontation between the world of poverty and wealth, we must be noble and docile consumers of the West's products" (p. 27). In this book, Jalal even suggests the solution of "Socializing large industries" to solve their problems (p. 166). Nevertheless, he finally sees the way of salvation in Islam and the unity of Muslims and he explicitly states that all of our troubles in history are due to the fact that Muslims did not feel at risk by attacks to the Islamic world, and when the enemies of Islam became alert in the ancient centuries, they fell into neglecting and took part in vain personal, social and ideological conflicts (p. 65). He criticizes the clergy of the society in the last century that the did not equip themselves with the enemy's weapon, and did not create a radio station in Qom or Mashhad, through which they could lead the people's insurrection at a large extent against the government. (P. 82). Additionally, in his description of the state of science and technology dependence in his Westernized country, Al-e-Ahmad is saddened by the fact that we are tame, docile consumers of the machine, we have surrendered to mechanism and we do not think about real independence and progress. In describing the relationship between Westernization and mechanism, he consciously cries that machine is a spell for Westernized people, who take refuge in it and consider themselves safe from all problems of the world, unaware of the fact that this is a spell others have put on us to scare and swindle us. Then, he says, "Undoubtedly, the same fear is the reason for Westernization, or because of Westernization, we are afflicted with such a fear (p. 120-121).

However, it can be stated that Al-e-Ahmad is seeking a solution to resolve all the things he calls "Westernization". In fact, in his view, the Westernization disease has a fundamental solution, which is to overcome the fear of Western mechanism and its structure in the first place, and then returning to selfidentity and religion. According to Al-e-Ahmad, the solution to the problem of Westernization is obvious; we must overcome the fear of Western mechanism, and in order to exit the crisis of identity and lack of cultural self-esteem, one must return to self and religion. Therefore, he found a great and exceptional opportunity to understand the solution to the grave problem of Iranian society and to find out the main reason 
of its captivity, abjection, and lack of self-esteem, namely, "Westernization" and powerfully and fairly criticize the colonial and westernized approach of the intellectual community of the Constitutional era and some other eras in Iran.

In fact, Jalal considered the phenomenon of Westernization with profound insights and presuppositions, whose theoretical significance was as follows, "He considered Westernization as an allembracing and influential approach, analyzed it in the framework of sociology, and while enumerating the features of Westernization, he identifies mechanism as its most important feature. In this regard, Jalal Al-eAhmad describes Iranian society as Westernized due to its specific characteristics, such as the internal conflicts and crises and considers the Iranian society afflicted by structural conflict. He does not merely identify the problems of the Iranian society (including Westernization), he also describes the negative consequences of this "aging" under the name of the War of Opposites, at a macro level with its structural impacts on society, and ultimately proposes a solution outlined in this section.

\section{Jalal Al-e-Ahmad and Returning to Self-Identity}

Fakhredin Shadman was largely a pioneer of Westernization discourse and emphasizing issues such as Iran's identity and cultural alienation towards a new lifestyle and the critique of Westernized semimodernists. However, in the 1960s, many writers and intellectuals focused on issues such as East and West, Westernization, opposition to the technique, the critique of new urbanization, and the emphasis on indigenous concepts against modernity and modernization crises. For this reason, the $60 \mathrm{~s}$ is the decade for the culmination of the nativist, a decade in which the dominance of the words "Westernization" and "returning to oneself" provided the theoretical means necessary for an Islamic intellectual movement in the following decades (Manouchehri and Abbasi, 2011: 302).

In this regard, one must say that the 1960s in Iran can be called the decade of "returning to self". Accordingly, it can be said that Al-e-Ahmad is one of the pioneers of this concept. Although "he played a pivotal role in developing the concept of returning to himself that his friend and colleague, Maleki, had initiated and his influence on the life and intellectual history of the Iranian nation was fundamental (Vahdat, 2004: 173); however, the subject of "turning to self" seems to have three aspects:

1. The return to the Islamic totality in opposition to "Westernization", which somehow evokes a kind of mixing of religious and political affairs. It is a kind of return that Jalal Al-e-Ahmad defends, which, of course, was political.

2. Returning to the carnal self that is mostly mysterious.

3. Returning to the village and the ancestral land, is in opposition to the "city", which follows the logic of returning to self that Jalal Al-e-Ahmad had mentioned was nothing but "nativism" (Pourchannari, 2016: 154).

In this period, as an intellectual and writer, Al-e-Ahmad emphasizes the preservation of traditions in the course of transformation and seeks to find a weapon for the influx of modernism and dependent capitalism. In pursuit of his intellectual activities and due to his attention to the disadvantages caused by the relationship with the West, he proposes the theory of returning to self and the thesis of coping with the effects of Western culture and civilization. He, who has experienced all the nationalist and left-wing remedies and is now criticizing foreign colonial policies, is now seeking refuge, and this refuge is a return to tradition (Amiri, 1993: 272); a return, with an obvious example in Nun Va'l Qalam, The Curse of the Earth, At the Service and Betrayal of the Intellectuals, and Occidentosis: A Plague by the West. 
In fact, the Cold War and the competitions between the Soviet Union and the United States, national liberation movements and anti-colonial movements started a new debate among the intellectuals of the 1960s and 1970s. Among them, one can mention, "Westernization", "cultural self-alienation" and "return to self".

He also considered those Iranian intellectuals, who viewed the West as an alternative, responsible for creating an atmosphere ready for the West to enter and dominate (Boroujerdi, 2000: 113). Al-e-Ahmad's problem with the intellectuals (especially the representatives of the constitutional movement) was their taking distance from Islamic traditions and modeling the modern civilization of the West. In sum, Al-eAhmad was the representative of a generation of Iranian intellectuals who were disillusioned both with liberalism and with socialism. His dissatisfaction with liberalism was rooted in the fact that the West, despite its promise of supporting democracy, brought for Iran nothing but old and new colonialism and support for autocratic rulers. Just as his frustration with socialism was the result of the Soviet expansionism, the defeat of the existing socialism was in fulfilling its promises and the submissive attitude of the leaders of the Tudeh party against the Soviet demands and policies (Hosseini Zadeh, 2008: 188). Finally, his process of evolution of thought and return to the indigenous roots of his own society revived in him.

On the other hand, Jalal Al-e-Ahmad uses "Westernization" as dependence on as a technological symbol of the West (Al-e-Ahmad, 2002: 31), and the political and economic following Western governments; which leads to the loss of our historical and cultural character and becoming dissolved in Western culture. In the words of Jalal Al-e-Ahmad, "The Westernized person is head over hills in love with the West. He does not care what happens in our cozy little world in the East. If he is a politician, he knows the slightest tendencies of the right and left-wing British labor party, and he knows the American senators better than his country's ministers. If he is a scholar, he misses out on all the investigative issues in the country, and he only follows what an Orientalist has said and has written about his investigative issues..." (Al-e-Ahmad, 2002: 130). For this reason, he opposes many of the ideas put forward by the government (and governmental intellectuals) during the White Revolution, and in particular, land reform, since he believes their implementation leads to the destruction of indigenous identity and greater dependence on the West. For example, he sees the Land Reform Act inconsistent with the arrival of technology in the village. In the story Curse of the Earth, he says, "The correct operation of the tractor was passed in violation of the land division act, because "The tractor is not familiar with boundary and structure. Its driver is also a foreigner, sir. When this happens, obviously, boundary and organization disappear, sir and the fight breaks out." (Al-e-Ahmad, 2009, p. 27). Disregarding this contradiction leads to Iran's backwardness and dependence, and it is desirable for the company because in practice this machine becomes useless.

In a situation where Iranian identity is in jeopardy, there are whispers among intellectuals about "searching their identity" and the idea of returning to its general meaning becomes the preoccupation of intellectuals and storytellers. Thus, from the year 1954, the discourse of identity took a special direction rejects the modernized identity entirely. During this period, the Nationalization of Oil Supplies and a critical approach towards the West brought a tradition-centered approach to the Iranian identity discourse and pushed Third World intellectuals more to their native identities and local traditions (Kachuian, 2004). Thus, the intellectuals of this period, with the rejection of the modernization of the West, called for "selfdiscovery" and "return to self". Therefore, essentially, the 1960s can be regarded as much as they are years of consolidation and growth of dependent capitalist relations and domination of foreign culture, the years of the reaction of many intellectuals and writers to consolidating those imposed relationships and the imported culture. The authors of this decade, who viewed national identity at risk of being destroyed, sought their identity. However, the remarkable thing about this is that intellectuals came up with different approaches in the process of reconstruction of national identity. Some such as Kasravi and Hedayat, with an emphasis on Iranianism instead of religious ideology, tried to introduce Islam as an element imposed on Iranian culture; and, in contrast to others, such as Shariati and Motahari, in defense of religious traditions, tried to reconstruct the religious identity. Shariati called returning to self as revival of human personality, historical and cultural originality, self-awareness and, finally, salvation from the disease of cultural alienation and spiritual 
colonization (Shariati, 1998: 94) and calls the self in this return as "a cultural Islamic self" that is closest to us and is the only culture and civilization that is alive today (Shariati, 1998: 96).

In fact, criticizing the intellectuals interested in the West, this time he introduced a new force for advancement in intellectual and political activities. Referring to the history of the Constitutional Revolution, he praised the role of the clergy in anti-autocratic struggles and reminded their vigilance in detecting the West's role in such movements and confronting them, as what Sheikh Fazlullah Nouri tried to do. He mentioned the clergy as a great stronghold for fostering indigenous thinking and confronting the indiscriminate influence of the West in Iran, and in general, he analyzed the role of religion in this regard very well. He considered the fight against intellectual, cultural, and political surrender to the West the only way to be rescued; he recognized the clergy as the only group capable of confronting this influence and he thought, given their popularity among the people, they would be able to make this resistance a widespread resistance. In his opinion, the clergy is the most qualified physicians who can provide this Iranian identity vaccine (Ale Ahmad, 1979: 118). His emphasis on Shia religion as a way of salvation can later be recognized by other intellectuals such as Shariati, who has admitted the undeniable influence of Jalal on themselves. This resulted in the Islamic Revolution a decade later in 1979. Accordingly, Al-e-Ahmad found all he was looking for in a religious identity, but not every religion, but a religion that is devoid of superstition and prejudice, capable of dealing with problems according to the needs of time to answer its problems; this is the beginning of the third way he proposes to the society to solve the problem of Westernization. This way means denying Westernization on the one hand and negating the escape into tradition and the fanatics of remaining captive of traditions and the primary tools of creation.

This means breaking the spell of machines, destroying the soul of the machine and making it a platform to jump that cannot be done unless it is prepared for (Al-e-Ahmad, 1993: 119). Therefore, what is seen in Al-e-Ahmad's works, especially Occidentosis: A Plague by the West, is a critique of modernism, decolonization and cultural colonialism, cultural alienation, mechanism, nativism, and identity. In this regard, as a pioneering theorist, he proposed the idea of "nativism" and "returning to self" with the aim of prescribing a solution to the crisis of the identity that dominated the community of his age.

In general, it should be acknowledged that the writing of Jalal Al-e-Ahmad's book Occidentosis: A Plague by the West by Jalal Al-e-Ahmad, resulted in four important achievements for Iranian society in the context of the issues of identity, the return to self, nativism, colonization, and intellectual society:

- First, by simply providing a critical balance of the 100-year-old intellectuals' work in Iran, it easily explained the complex issues that this changing society was confronted with;

- Second, by raising the issue of national and ethnic identity again, a nationalist alternative was developed against the internationalist view of the Iranian left-wing forces when they enjoyed great power;

- Third, by providing an important issue for the era and traditions that were gradually removed from memories, made a third world discourse that was skeptical of what the West had to offer;

- Fourth, he called on Iranian intellectuals to come to their senses and confront the hegemony of the foreign culture that was about to overshadow the intellectual, political and economic life of Iranian society (Boroujerdi, 2000: 111).

It should be noted that Jalal Al-e-Ahmad is one of the few thinkers who dealt with the religion and its role in society and culture of Iran in his social studies. However, his attitude towards religion and the clergy has not always been reflected in the same way. Despite his rejection of retrogressive understandings of religion and showing his opposition to the traditional religion, which was usually combined with superstitions and prejudice, and regarding it as recessive, from his point of view, progressive religion is considered as a determining factor in identifying Iranian identity. The concept of Westernization in Jalal Ale-Ahmad's thinking involves the transformation of the identity of the native culture of Third World countries 
(colonies). To this end, in addition to emphasizing the need to achieve the power of machine manufacturing technology, he refers to the return to tradition and reliance on the historical and cultural origins of Third World nations (cultural hegemony) as a solution to overcome Westernization.

In this regard, Jalal Al-e-Ahmad believed that one had to balance between society, culture, and tradition, and it seems that for this reason, it is also necessary to insist on the necessity of returning to selfidentity. In this sense, tradition is considered as a source of struggle and resistance against the West (in its political sense), colonialism, and the government.

\section{Conclusion}

Occidentosis: A Plague by the West and at the Service and Betrayal of Intellectuals are post-colonial writings that illustrate the consequences of the colonial presence as well as the Westernization of society, and expound the role and position of intellectuals in the process. Therefore, it should be stated that the foundation of Al-e-Ahmad's thinking in his works is, in fact, finding the contradictory layers and conflicts arising from the confrontation of two conflicting cultures as a result of Western cultural colonization, and the two above-mentioned works are no exception to this rule. The content of his thoughts in these works is a contrast of the formation of the confrontation of the arrogant West and the subordinate East (in a sense colonial/ colonized relations). In this unequal image, Iran, in particular after the coup d'état of August 19, 1953 becomes a symbol of a colonized society that, unconsciously and in vain, exchanges its national capital for industrial goods and machine tools. Therefore, Al-e-Ahmad considers cultural exploitation as the prelude to economic and political exploitation and considers the effort for a nationalized self-awareness only in returning to self-identity and nativism.

Accordingly, it can be said that post-colonialist theory played an important role in challenging the supremacy of the West and defending the equal negotiation between developed countries and Third World. Western colonialist discourse has been formed by the spread of Western colonialism and Europecenteredness. It is also worth noting that elements such as the expansionism of Western colonizers and Europe-centeredness constitute two main components of the post-colonialist theory. In addition, Western colonizers saw colonized people as "the others" lacking ability to think and lacking self-esteem; they often compared Eastern peoples based on Western values, and therefore, the Eastern nations were backward, deprived, uncivilized, etc.

This issue, which, according to experts, as defined and interpreted in the context of the West's "cultural hegemony", in turn, provided grounds for resistance against colonialism and the preservation of national values in the colonies. Therefore, in practical terms, we witnessed the formation of anti-colonial movements in the colonies, and in practical terms, it led Jalal Al-e-Ahmad to present his critical opinion and wrote the book Occidentosis: A Plague by the West.

In fact, Al-e Ahmad portrays his views and interpretations based on two levels of colonialist thinking, namely political and economic exploitation, and cultural exploitation, and presents ways to emancipate from colonization by returning to self and reviving the national and indigenous identity of Iran. Thus, like post-colonial writings, it depicts the tendency towards the cultural and political independence of nations and resistance to colonialism.

It can be said that Jalal Al-e-Ahmad considered the idea of Westernization and returning to selfidentity from within its society and dealt with the issues of his society using a political and cultural approach. This is reflected in the identity component in the form of national identity and return to self-identity; in the intellectual component as his role in the formation of the society against the imported cultures; in the component of colonialism as cultural and economic colonialism; and in the category of Westernization, the 
same method of self-identification has been put forward as the most important method. Therefore, in this research, while responding to the question that what the places of Westernization and the return to selfidentity are in the thought of Jalal Al-e-Ahmad, this hypothesis was tested that by turning to story and article writing, Sayyid Jalal Al-e-Ahmad, proposed the concern to return to self-identity, he criticized modernity in Occidentosis: A Plague by the West; then he emphasized the identity and historical traditions that were discussed in detail in this study. In addition, in addition to studying Jalal Al-e-Ahmad's political life, his thoughts and views on Westernization were examined with an emphasis on the post-colonialism theory.

\section{References}

Al-e-Ahmad Sayyid Jalal (1969), in the service and betrayal of intellectuals, Tehran: Ravaq.

Al-e-Ahmad Sayyid Jalal (1974), Kharg Island in the Gulf orphan, Tehran: Amir Kabir.

Al-e-Ahmad Sayyid Jalal (1979), Karnameh 3 sale, Tehran: Ravaq.

Al-e-Ahmad Sayyid Jalal (1996), Westernization, Third Edition, Tehran: Ferdows Publications.

Al-e-Ahmad Sayyid Jalal (1997), a well and two pits, for example, a description of the tribes, Tehran: Ferdows Publications.

Amiri Manouchehr (1992), Russian and British in Iran (1914-1864): A Study on Imperialism, Translated by: Manouchehr Amiri, Tehran: Teaching Islamic Revolution,

An Opportunity for Joining Reza; Rahimi Dun Fatemeh (2011), Comparison of the View of Jalal Al Ahmad and Mostafa Lotfi Monafloty in the Sphere of Intellectuality and Westernization, Comparative Literature, 20.

Barnett Clive (2006), Postcolonialism: Space, Textuality, and Power, In: Aitken, Stuart and Valentine, Gill eds. Approaches to Human Geography. London, UK: Sage.

Bashiri, Mahmoud (2011), Jalal Pezhohi (Collection of articles about the opinions and opinions of Jalal Ale Ahmad by a group of writers), Tehran: Book House Publishing, First Edition.

Boroujerdi Mehrzad (2003), Iranian and Western intellectuals, Jamshid Shirazi translation Tehran: Farozan publishing.

Dasheghib Abdolali (1992), Review of Jalal Al-e Ahmad Works, Tehran: Zharf.

Davari Ardakani Reza (2004), Comparative Philosophy, Tehran: Saghei.

Davari Ardakani Reza (2005), We and the Difficult Way of Modernity, Tehran: Saghei.

Davari Ardakani Reza (2013), About the West, Tehran: Hermes.

Dibaj, Seyyed Mousa (2005 Opinions of Sayyid Ahmad Fardid: Mofradat Fardidi, Tehran: Elm.

Fadai Mehrabani Mehdi and Amin Moeini (2017), Comparative Study of Malkom Khan and Jalal AlAhmad's Thoughts; From Modernism to Iranian-Islamic Identity, Faculty of Law and Political Science, 47 (3). 
Fardid Ahmad (2016), The West and Westernization and the crisis of its historic issues are not in time. It seems that Lil and Lilly are tricky at the end of the day, the lessons of Sayyed Ahmed Fardid, the first one, Fader's philosophical and philosophical foundation.

Francis Toni P. (2007), Identity politics: Postcolonial theory and writing program instruction, Graduate Theses and Dissertations, University of South Florida, Scholar Commons.

Go Julian (2018) Relational Sociology and Postcolonial Theory: Sketches of a "Postcolonial Relationalism". In: Dépelteau F. (Eds) the Palgrave Handbook of Relational Sociology. Palgrave Macmillan, Cham

Hosseini Zadeh Mohammad Ali (2007), Political Islam in Iran, Qom: Mubarak Qom University Press.

Jahani Mehrzad (1983), Miyad with Jalal, Tehran: Ferdows Publications.

Manuchehri Abbas and Abbasi Muslim (2010), the Process of Formation of Political Thought Jalal AlAhmad: "Return to Self", Quarterly Journal of Politics, 40 (4).

Mesbahipur Pour, Jamshid (2002), the Social Reality and the World of Story, Tehran: Amir Kabir.

Mirsepasi Ali (2005), Iranian intellectuals; Yas and Omid narratives, translated by Abbas Mokber, Tehran: Development publication.

Pourcharnari Mohammad Abdolah (2015), Returning to itself as a tradition of (Case Study of Jalal AlAhmad), Political Journal, Faculty of Law and Political Science, 46 (1).

Saedi Ahmad Reza (2014), Post-Colonial Discourse Analysis in the Novel "Sharafat Allahzian" by Ibrahim Nasrallah, resistance Literature, 7 (13).

Shafiei Ghahfarhi Omid (2009), Jalal Al-e Ahmad and his relation to intellectual discourse, Rahavard-e Siyasi.

Shayegan Dariush (2009), Asia versus the West; Tehran: Amir Kabir.

Taebi Zohreh and Heidari Fatemeh (2014), Review of post-colonial discourse and its manifestations in translation of one year's travelogue among Iranian people, language studies and translation, 1.

\section{Copyrights}

Copyright for this article is retained by the author(s), with first publication rights granted to the journal.

This is an open-access article distributed under the terms and conditions of the Creative Commons Attribution license (http://creativecommons.org/licenses/by/4.0/). 